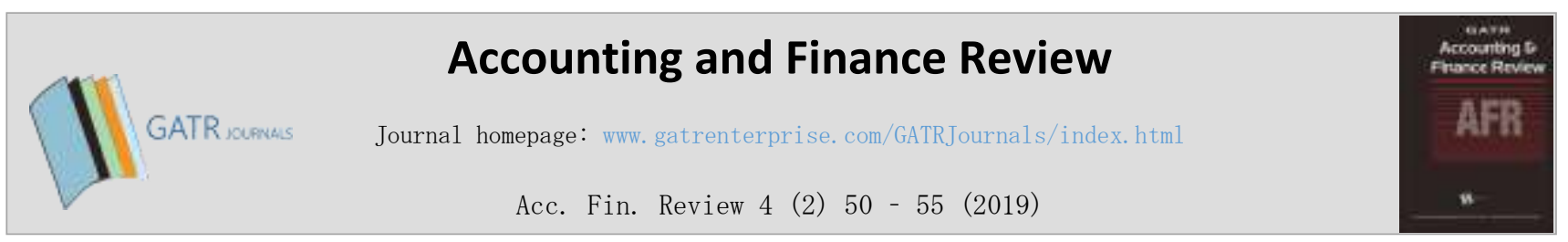

\title{
Earnings Management and Fraudulent Financial Reporting
}

\author{
Rosita Suryaningsih, ${ }^{\text {a* Febryanti Simon }}{ }^{\mathrm{b}}$ \\ ${ }^{a}$ Universitas Multimedia Nusantara, Scientia Garden, Jl Boulevard Gading Serpong, 15811, Tangerang, Indonesia \\ ${ }^{\mathrm{b}}$ Universitas Multimedia Nusantara, Scientia Garden, Jl Boulevard Gading Serpong, 15811, Tangerang, Indonesia
}

\section{ABSTRACT}

Objective - The objective of this research is to obtain empirical evidence about the effect of real earnings management that is proxied by abnormal Cash Flow from operating and discretionary expenses towards fraudulent financial reporting.

Methodology/Technique - The objects in this research are companies listed on the Indonesian Stock Exchange (idx) between 2011 and 2015 comprised of companies that have engaged in fraudulent activities as well as those that have not, to enable a comparison to be made. The companies that have engaged in fraudulent financial reporting were obtained from a list issued by the Financial Services Authority (OJK), being the agency that oversees the capital market in Indonesia. The sampling is conducted using purposive sampling. Secondary data is used, and the hypotheses are testing using logistic regression analysis.

Findings - The results of this research show that: (1) Real Earning Management proxied by Abnormal Cash Flow from operating activities (CFO) have a significant effect towards Fraudulent Financial Reporting (FFR), (2) Real Earning Management proxied by Abnormal Discretionary Expenses does not have an effect on Fraudulent Financial Reporting (FFR) and (3) Real Earning Management that is proxied by Abnormal Cash Flow from operating (CFO) and Abnormal Discretionary Expenses have a simultaneous and significant effect on Fraudulent Financial Reporting (FFR).

Novelty - Based on these findings, this research provides insight to companies to enable them to give greater attention to abnormal cash flow from operating activities due to the effect this has on companies that are suspected of committing irregularities in its operational activities. This is important because fraudulent reporting can erode investor's confidence and thereby reduce investment in the company.

Type of Paper: Empirical.

Keywords: Abnormal Cash Flow; Abnormal Discretionary Expenses; Financial Services Authority (OJK); Fraudulent Financial Reporting; Real Earning Management.

Reference to this paper should be made as follows: Suryaningsih, R; Simonb F; (2019). Earnings Management and Fraudulent Financial Reporting, Acc. Fin. Review, 4 (2): 50 - 55 https://doi.org/10.35609/afr.2019.4.2(3)

\section{JEL Classification:}

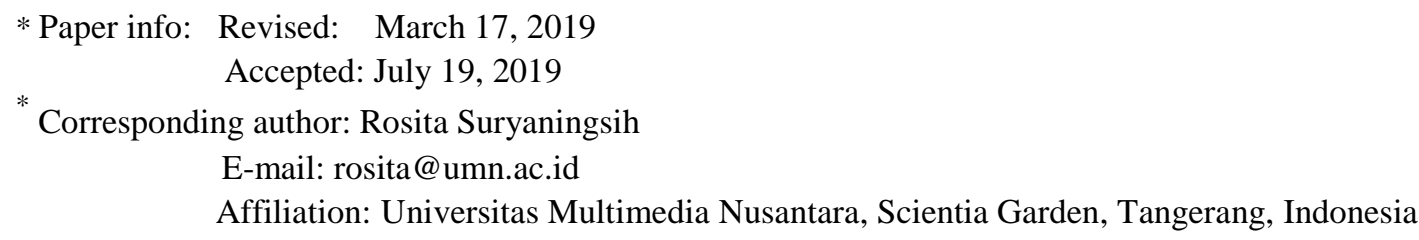




\section{Introduction}

The financial statements of a company provide information on the company's financial position and the performance of the company which can be used by investors when making investment decisions. Investors will invest their funds in companies that demonstrate high performance as investors wish obtain an optimal return. Therefore, the company is constantly working to improve the value of the firm that is reflected in their financial statements each year. Investors are mostly concerned with a company's profit. Earnings management is one of the ways that the management of a company can achieve their profit targets and can therefore become more appealing to investors (Carcello, 2004).

However, the implementation of earning management that is too aggressive can raise suspicions that a company has engaged in fraudulent financial reporting. The companies examined in this study that have engaged in fraudulent financial reporting were obtained from a list issued by the Financial Services Authority (OJK), being the agency that oversees the capital market in Indonesia. This research will demonstrate the effect of real earnings management that is proxied by abnormal CFO and discretionary expenses on fraudulent financial reporting (Rahman, 2006).

\section{Literature Review}

\subsection{Fraud}

The American Institute of CPAs or AICPA (2012) defines fraud as a deliberate act of fraud by someone or several people in management, the government, employees, or third parties, to obtain illegal benefits. Kieso (2019) defines fraud as a dishonest act by an employee that results in personal benefit to the employee at a cost to the employer. Many fraud related studies are based on the theory put forward by Cressey in 1953 known as the "Fraud Triangle". According to the fraud triangle theory, fraud can occur due to three variables: pressure, opportunity and rationalization.

Figure 2.1 Fraud Triangle

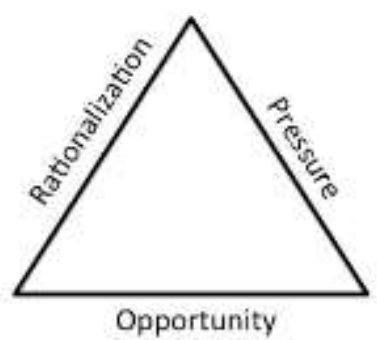

\subsection{Earnings Management}

Research by Perols and Lougee (2011) found that the likelihood of fraud was significantly greater in companies that had previously engaged in earnings management. According to Stolowy and Breton (2003) in Ratmono (2010), fraud and earnings management are two different things; fraud is illegal and is beyond the scope of accounting standards while earnings management is within the scope of accounting standards and is a form of account manipulation. Earnings management is the use of flexibility in accounting standards to manage accounts with the aim of presenting certain profits or other objectives (Ratmono, 2010).

Marai and Pavlovic (2013) state that there are 2 characteristics in earnings management. First, earnings management is a conscious and deliberate action taken by management, with the aim of changing the profits presented. Therefore, earnings management is different from profit misstatements made by management which is done accidentally. Second, earnings management can be done through an accounting system or company business transaction. Earnings management through an accounting system is also known as 
Accrual-based Earnings Management (AEM), which includes the use of estimates or judgments that are permitted in accounting rules or standards, such as estimated useful lives on long-term assets, uncollectible accounts, and other estimates (Davidson, 2005). On the other hand, earnings management through company business transactions is also known as Real Earnings Management (REM), which includes the manipulation of real transactions that can change the presentation of earnings so that earnings management objectives can be achieved. Some examples of REM include changes in production, price changes, and others (Dechow, 2000).

Fraud actors must have a basic understanding of standards and operations to manage earnings with the aim of achieving profit targets. Earnings management actions can arise from agency friction, particularly when management wants to maximize personal gain or pressure to provide quality financial information to company shareholders. However, when the pressure to achieve profit targets increases, earnings quality is no longer a priority, but is replaced by personal gain which often leads to fraud (Rahman et. al., 2016).

In our empirical tests, we use two items (no. 1 and 2) from three real earnings management measures, as developed in prior research (Roychowdhury, 2006; Cohen et. al., 2008; Cohen \& Zarowin, 2010; Zamri et. al., 2013; Achleitner et. al., 2014; Sun et. al., 2014; Baatour et. al., 2019):

(1) abnormal cash flows from operations;

(2) abnormal discretionary expenses; and

(3) abnormal production costs.

Previous research by Rahman et. al. (2016) examining 57 companies in Malaysia that have indicated fraud actions found that there was a significant negative relationship between accruals earnings management and real earnings management in the period before and during when the fraud was discovered. However, in the year after the fraud, research shows that companies tend to switch to using real earnings management. The results of research by Perols and Lougee (2011) on 108 companies in the United States showed a significant positive relationship between aggregated discretionary accruals 3 years before the year of the fraud event with companies that have indicated fraud. Based on the background of this paper and the literature above, the hypotheses for this study are as follows:

Ha1: Real Earnings Management that is proxied by abnormal CFO has an effect on FFR.

Ha2: Real Earnings Management that is proxied by abnormal discretionary expenses has an effect on FFR.

Below is the research model:

\begin{tabular}{|c|c|}
\hline Abnormal CFO & $\begin{array}{c}\text { Fraudulent Financial Reporting } \\
\text { (FFR) }\end{array}$ \\
\hline Abnormal Discretionary expenses & \\
\hline
\end{tabular}

\section{Research Methodology}

This research is a causal study, which aims to explain the relationship between an event that causes another occurrence (Indriantoro \& Supomo, 2013). The data used in the study is secondary data in the form of the company's annual financial statements obtained from the official website of the IDX at http://www.idx.co.id, and a database of FSA sanctions from 2011 to 2015 obtained from the Directorate of Sanctions and Objection Determination offices FSA Capital Market in Indonesia. In this research, we use 20 firms that engage in FFR and 20 firms do not engage in FFR. This research uses a logistic regression method. 


\section{Independent Variable}

1. Abnormal Cash flow from operations (CFO)

Real Earnings Management that is proxy by abnormal CFO:

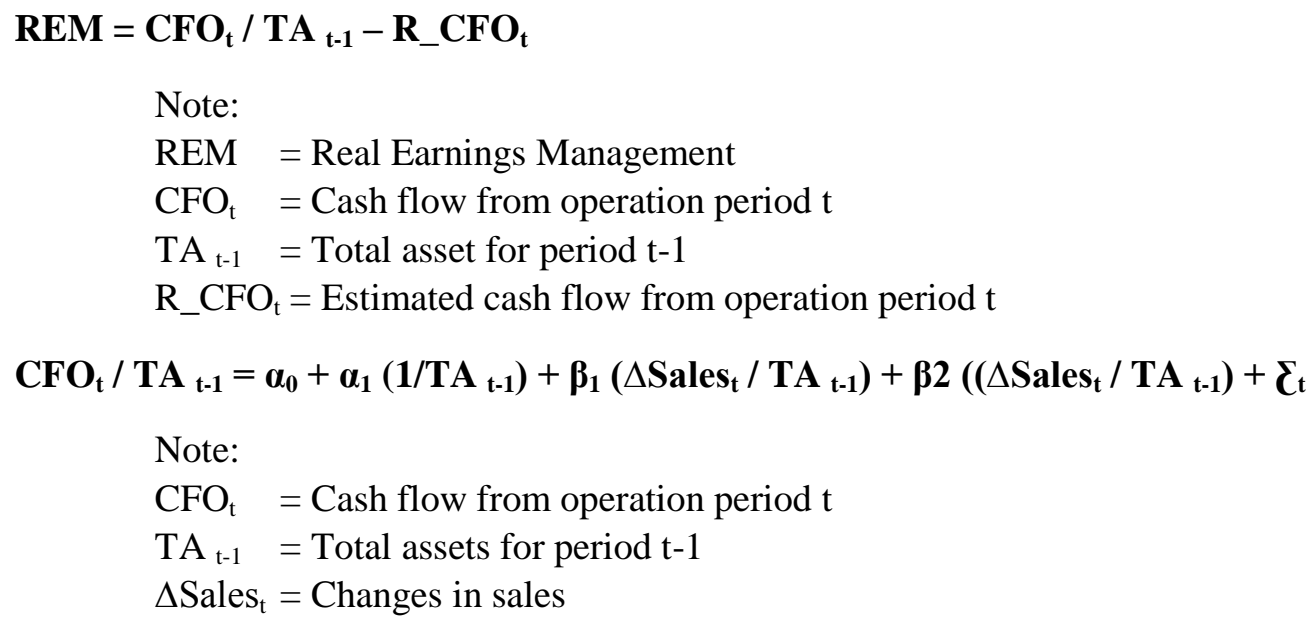

We then calculate the R_CFO:

$$
\text { R_CFO }{ }_{t}=\alpha_{0}+\alpha_{1}\left(1 / \text { TA }_{t-1}\right)+\beta_{1}\left(\Delta \text { Sales }_{t} / \text { TA }_{\mathrm{t}-1}\right)+\beta 2\left(\left(\Delta \text { Sales }_{t} / \text { TA }_{\mathrm{t}-1}\right)+\boldsymbol{C}_{\mathrm{t}}\right.
$$

2. Abnormal Discretionary Expenses (DE)

Real Earnings Management that is proxy by discretionary expenses:

$$
\mathrm{DE}_{\mathrm{it}}=\boldsymbol{\beta}_{0}+\boldsymbol{\beta}_{1} / \text { Assets }_{\mathrm{it}-1}+\boldsymbol{\beta 2 S}_{\text {Sales }} \text { it-1 }_{1} / \text { Assets }_{\mathrm{it}-1}+\boldsymbol{\zeta}_{\mathrm{it}}
$$

Note:

$\mathrm{DE}_{\mathrm{it}} \quad=$ Total expense from $\mathrm{R} \& \mathrm{D}$, advertising expense, selling expense, general and administrative expense

Assets ${ }_{\text {it-1 }} \quad=$ total asset for period $\mathrm{t}$

Sales $_{\text {it }-1} \quad=$ total sales for period $\mathrm{t}-1$

\section{Results}

Below are the results of the hypothesis testing:

Table 4.1. Coefficient of Determination

\begin{tabular}{cccc}
\hline Step & -2 Log likelihood & Cox \& Snell R Square & Nagelkerke R Square \\
\hline 1 & 48.560 & 0.158 & 0.211
\end{tabular}

Based on the SPSS output as shown in Table 4.1, the value of the Nagelkerke's R Square is 0.211, which means that there is an abnormal CFO and DE which can be used to explain the FFR of $21.1 \%$. The remaining $78.9 \%$ is explained by other variables outside of the research model.

Table 4.2. Hosmer and Lemeshow Test

\begin{tabular}{cccc}
\hline Step & Chi-square & df & Sig. \\
\hline 1 & 7.614 & 8 & 0.472
\end{tabular}


According to Table 4.2, the value of the Hosmer and Lemeshow test has a significance level of 0.472 which is greater than 0.05 . This means that the model is able to predict the value of this observation (FFR).

Table 4.3. Omnibus Tests of Model Coefficients

\begin{tabular}{ccccc}
\hline & Chi-square & df & Sig \\
\hline Step 1 & DE & 6.892 & 2 & 0.032 \\
& CFO & 6.892 & 2 & 0.032 \\
& Constant & 6.892 & 2 & 0.032
\end{tabular}

Table 4.3 indicates that the value of the chi-square is 6.892 with a value significance of 0.032 , being smaller than 0.05 . Thus, it can be concluded that the abnormal CFO and DE variables have a simultaneous significant effect on FFR.

Table 4.4. Results

\begin{tabular}{cccccccc}
\hline & & B & SE & Wald & df & Sig & $\operatorname{Exp}(\mathrm{B})$ \\
\hline Step 1 & DE & -0.001 & 0.001 & 1.718 & 1 & 0.190 & 0.999 \\
& CFO & 4.730 & 2.834 & 2.786 & 1 & 0.095 & 113.273 \\
& Constant & -0.028 & 0.347 & 0.006 & 1 & 0.936 & 0.972
\end{tabular}

Based on Table 4.4, an abnormal CFO has a significant effect on Fraudulent Financial Reporting (FFR), which is apparent from the significance value of 0.095 which is smaller than 0.1 (10\% significant level). This means that $\mathrm{Ha} 1$ is accepted. As for abnormal DE, the significance is 0.190 which is greater than 0.1 , meaning that $\mathrm{Ha} 2$ is not accepted.

The results of this research are as follows:

(1) Real Earning Management proxied by Abnormal Cash Flow from Operations (CFO) has a significantly effect on Fraudulent Financial Reporting (FFR).

(2) Real Earning Management proxied by Abnormal Discretionary Expenses does not have an effect on Fraudulent Financial Reporting (FFR).

(3) Real Earning Management proxied by Abnormal Cash Flow from Operations (CFO) and Abnormal Discretionary Expenses have a simultaneous and significant effect on Fraudulent Financial Reporting (FFR).

\section{Discussion}

The results of this study indicate that abnormal CFO has a significant effect on FFR. This suggests that companies should pay greater attention to abnormal cash flow from operations because this raises suspicions of irregularities in their operational activities. This can erode the confidence of investors and thereby reduce investment in the company.

As for abnormal DE, the results show that it has no effect on FFR. Based on the research data, it is known that $\mathrm{DE}$ should be used in the calculation of RD, advertising, selling, and GA costs. However, the data shows that the entire sample of companies only issue marketing and GA costs, so not all elements of the DE cost calculations are met. In addition, from the four types of costs above, the most difficult costs to estimate is RD and advertising expenses, which of course contribute to the catalyst of real earning management. This is what we predicted as the cause of abnormal DE has no effect towards Fraudulent Financial Reporting. Based on the results of the hypothesis testing as shown in Table 4.4, the logistic regression equation formed is: 
The log of odds of the sample company predicted to be included in the list of companies experiencing Fraudulent Financial Reporting is positive for abnormal CFO variables and negative for abnormal variables DE. Every abnormal increase in CFO will increase the log of odds of the company predicted to be included in the list of companies experiencing Fraudulent Financial Reporting which is 4,730. If Abnormal CFO is considered constant, then every increase in Abnormal DE will decrease the log of odds of the company predicted to be included in the list of companies experiencing Fraudulent Financial Reporting which is 0.001.

\section{Conclusion}

Based on the results of this study, Real Earning Management proxied by Abnormal Cash Flow from Operations (CFO) have a significantly effect on Fraudulent Financial Reporting (FFR). This research provides insight to companies and encourages them to pay greater attention to abnormal cash flow from operations as this raises suspicions of irregularities in operational activities. This can erode the confidence of investors and can thereby reduce investment in the company.

\section{References}

\section{Journal article}

Abdul Rahman, R., \& Haneem Mohamed Ali, F. (2006). Board, audit committee, culture and earnings management: Malaysian evidence. Managerial Auditing Journal, 21(7), 783-804, https://doi.org/10.1108/02686900610680549

Baatour, K., Ben Othman, H., \& Hussainey, K. (2017). The effect of multiple directorships on real and accrual-based earnings management: Evidence from Saudi listed firms. Accounting Research Journal, 30(4), 395412.https://doi.org/10.1108/ARJ-06-2015-0081.

Carcello, J. V., \& Nagy, A. L. (2004). Audit firm tenure and fraudulent financial reporting. Auditing: a journal of practice \& theory, 23(2), 55-69, https://doi.org/10.2308/aud.2004.23.2.55

Davidson, R., Goodwin- Stewart, J., \& Kent, P. (2005). Internal governance structures and earnings management. Accounting \& Finance, 45(2), 241-267, https://doi.org/10.1111/j.1467-629x.2004.00132.x

Darmawan, Nyoman, Interviewed, By Kadek, Partami, By Luh. 2015. "The Effect of Real Earning Management Towards Firms Values with Corporate Governance as a Moderating Variable”. E-journal S1 Ak Ganesh University of Education. Volume 3 No. 1.

Dechow, P. M., \& Skinner, D. J. (2000). Earnings management: Reconciling the views of accounting academics, practitioners, and regulators. Accounting horizons, 14(2), 235-250, https://doi.org/10.2308/acch.2000.14.2.235

Ghozali, I. (2013). Multivariate analysis applications with IBM SPSS 21 Program Update PLS Regression.

Hasnan, S., Rahman, R. A., \& Mahenthiran, S. (2012). Management motive, weak governance, earnings management, and fraudulent financial reporting: Malaysian evidence. Journal of International Accounting Research, 12(1), 1-27. https://doi.org/10.2308/jiar-50353.

Marai, A., \& Pavlovic, V. (2013). Earnings management vs financial reporting fraud-key features for distinguishing. Facta Universitatis Series: Economic and Organization, 10, 39-47.

Rahman, R. A., Sulaiman, S., Fadel, E. S., \& Kazemian, S. (2016). Earnings management and fraudulent financial reporting: The Malaysian story. Journal of Modern Accounting and Auditing, 12(2), 91-101, doi: 10.17265/1548$6583 / 2016.02 .003$

\section{Books}

Accountants Association of Indonesia. (2017). Financial Accounting Standard. Jakarta: Fourth

Tuanakotta, Theodorus M. 2014. Forensic Accounting \& Investigative Audit. Jakarta: Fourth. 